\title{
STUDENT TO SELF-FEEDBACK IN IMPROVING STUDENTS' SPEAKING ABILITY
}

\author{
Rizka Indahyanti \\ Prodi Bahasa Inggris \\ Universitas Islam Makassar \\ rizkaindahyanti@uim-makassar.ac.id \\ Mutmainnah Mursidin \\ Universitas Islam Makassar \\ muthmainnahmursidin23@yahoo.com
}

\begin{abstract}
This research is basically aimed to test the Student to self-feedback method in improving their speaking ability. Furthermore, it is aimed to see the effectiveness of colleagues in helping other friends to learn. The method used in this research is Quantitative method with quasi-experimental setting in its test. The step of this research includes the field observation, pre-test, giving treatment by applying student to self-feedback method, then post-test. One by one the student talks then another friend judge what the strengths and the weaknesses of his friend. The instruments used in this research are speaking test and questionnaire. The written assessment contained in the assessment aspect includes: fluency, accuracy and comprehensibility. The population in this research is all English education students of FKIP UIM. While the sample used is the second semester students. The researchers divided the class into 2 groups. One group as the experimental class and the other as the control class.The results of the data analysis show that the probability is less than 0.05 or $0.000<0.05$. This means that H1 is acceptable and, of course, the statistical hypothesis $\mathrm{HO}$ is rejected. Therefore, it can be concluded that the use of Student to self-feedback method improves their speaking ability.
\end{abstract}

Keywords: Student to Self-feedback, Speaking ability

\begin{abstract}
ABSTRAK
Penelitian ini pada dasarnya bertujuan untuk mengujicobakan kemampuan Student to self-feedback dalam meningkatkan kemampuan berbicara mahasiswa. Selanjutnya, penelitian ini bertujuan untuk melihat keefektifan teman dalam membantu teman-teman lain untuk belajar. Metode yang digunakan dalam penelitian ini adalah metode Kuantitatif dengan setting quasi-experimental dalam pengujiannya. Langkah penelitian ini meliputi observasi lapangan, pre-test, pemberian perlakuan dengan menerapkan metode student to self-feedback, kemudian post-test. Satu per satu mahasiswa tersebut berbicara kemudian teman lain menilai apa kelebihan dan kekurangan temannya. Instrumen yang digunakan dalam penelitian ini adalah tes berbicara dan kuesioner. Penilaian tertulis yang terkandung dalam aspek penilaian meliputi: fluency, accuracy and comprehensibility. Populasi dalam penelitian ini adalah semua mahasiswa pendidikan bahasa Inggris dari FKIP UIM. Sedangkan sampel yang digunakan adalah mahasiswa semester II. Peneliti membagi kelas menjadi 2 kelompok. Satu kelompok sebagai kelas eksperimen dan yang lainnya sebagai kelas kontrol. Hasil
\end{abstract}


analisis data menunjukkan bahwa probabilitasnya kurang dari 0,05 atau 0,000 $<0,05$. Ini berarti HI dapat diterima dan, tentu saja, hipotesis statistik HO ditolak. Oleh karena itu, dapat disimpulkan bahwa penggunaan metode Student to selffeedback meningkatkan kemampuan berbicara mahasiswa.

\section{Keywords: Student to Self-feedback, Kemampuan Speaking}

Now days, English has an important role because it is used as an international language. For some students, English is only a general course in learning process, but for others it is important to know, of course, with certain reasons. Without realizing, English becomes increasingly important along with the development of technology in all fields. The information presented in the development of this technology mostly use English; therefore, to access, it requires at least some vocabularies to understand the intent of the information. English as the most popular language in the world becomes the most intention by many people to learn. This makes English looks as the essential subject in any educational unit, even becomes the priority in some countries like Indonesia. For university level, English is taught in all departments. Even though, English is only as the general subject for non-English major and taught only for one semester. Furthermore, English is not only essential in teaching and learning activities but also in testing. It is one of important subjects for the students to pass the national examination. It becomes one subject to enter the university, even for magister degree, the test of English such a TOEFL test is required. Therefore, it cannot be denied that English seems the integrated part of our educational practices. But those also cannot help the Indonesian students to be a good communicator in English, even after learning English for years.

This reality leads us to evaluate the teaching and learning process applied by the lecturers and the students. A good process will produce a quality outcome and vice versa. In supporting a good learning process, we should have good resources, facilities, and method as well. This is fully supported by the government by promoting training and special education for all educators in the country.

Talking about English, speaking skill is the most important among skills, especially in English learning process. This is because speaking is the most easily measured and most important skill in its utilization. Some teachers and lecturers may have different ways or methods of teaching. Therefore, different teaching 
standards are required in order to reach all students. The method chosen should be as efficient and effective as possible. The method applied must be well targeted and measurable in order to see the improvement of students' speaking ability significantly. By knowing the sides of the student's lack of learning in speaking, it will be easier to emphasize the treatment to each student based on their shortcomings. One of aspects that encourage their motivation in speaking English is the feedback giving by their lecturers and their friends. Therefore, from the background, the researchers formulated a feedback-based method of learning and self-correction based on the theory of Hall (2007) which is still rarely encountered in language learning is applied in speaking learning with the title "Student to selffeedback in Improving Students' Speaking ability”.

\section{Research statement}

From the description of the background above, it can be formulated research statement as follows:

a. Does the use of the student to self-feedback method improve the speaking ability of English education students of FKIP UIM?

b. Are the students interested in using student to self-feedback method in improving their speaking ability?

\section{Research Objectives}

In line with the formulation of the research statement above, the objective of this research is as follows:

a. To find out whether or not the use of student to self-feedback method improves the speaking ability of English education students of FKIP UIM.

b. To find out whether or not the students are interested in using student to self-feedback method in improving their speaking ability.

\section{Research Significance}

This research is conducted to produce an effective learning method that will certainly have some benefits for the parties concerned. For teachers and lecturers, this method is used as an effective teaching solution in improving the quality of their students' speaking. For students, it will certainly be a new experience in a teaching method with a self-correction based. They will know the extent of their 
lack of learning in speaking. Therefore, it will encourage them to try harder in improving their speaking skill.

\section{Speaking Concepts}

Speaking is one of four skills that are commonly present in every language. Speaking is a daily activity by humans to socialize and express their desires and needs. Speaking includes the most dominant communication tool used by the public. By issuing certain sounds that have meaning then people will know what we want or indicate.

According to Tarigan (2008) speaking is an activity of disclosure of ideas prepared according to the needs of listening or listeners with the aim of communication awakening. Speaking is the second linguistic activity performed by humans after the first is the listening activity (Nurgiantoro: 2001).

Speaking is a productive skill in the sense that speaking is produced by a speaker into a speech commodity. With productive nature, then speaking will be very closely related to listening activity as a receptive skill. In the activity of responding, the speaking process should at least be preceded by listening activity as input to be processed and ultimately produce speech as a result of the listening activity.

\section{Feedback in learning}

In this section will be explained things related to feedback or feedback in learning starting from the sense, its types and its application.

1. Definition of feedback

Feedback is a word in English that Indonesians have said very often as the representation of the word feedback. While in the context of learning, feedback is often identical with the response to the actions of students, whether it is done by students or teachers and lecturers. According to Arikunto (2009: 5), feedback is all information both about output and transformation. The transformation here is the machine in charge of converting raw materials into finished materials. In other words, feedback is a process of providing useful information for students to examine skills related to their appearance and monitor their own learning progress. According to Race, Feedback is basically something that happens as a 
result of action in the learning process. According to him feedback can be done after the action, before or at the same time. He also placed feedback on the outer circle as depicted in the ripple diagram on the pond as below.

\section{Ripple on a Pond}

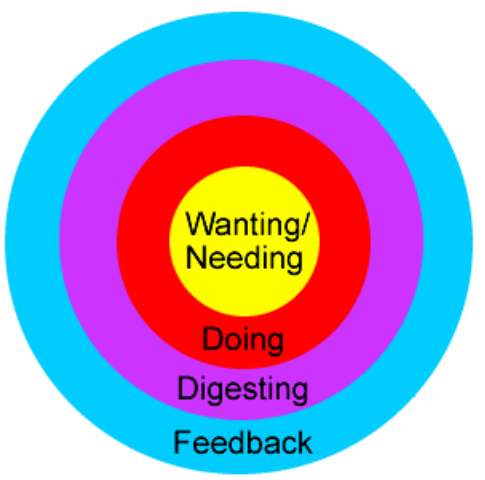

Feedback includes a very important part of learning because it will affect a lot of motivation and interest in learning students or students Suhadi (2008). A learner may find it difficult to measure his ability in a course until they are given feedback in the form of feedback or constructive criticism. According to Herman in Wisdom (2014), this feedback can be intrinsic and extrinsic. Intrinsic feedback is inherent information with respect to the quality of appearance that the individual gains during the activity process. While in contrast to extrinsic feedback information relating to the quality or accuracy of individual appearances is obtained from the intermediary of another person or person.

A study conducted by Seruni and Nurul (2014) shows that the use of feedback or feedback can improve student learning outcomes and interest in learning math. Similarly, research conducted by Wahyu et al shows that there is a significant difference in learning outcomes between classes given the feedback treatment with a class that is not. The use of feedback in learning seems to work well in science, then researchers will try to apply this feedback in linguistics and see how far the results end. 


\section{Types of Feedback in Learning}

There are several groupings of feedback types that some experts have classified differently.

a. The types of feedback according to Hall (2007)

1) Feedback for Teacher to Student is the teacher giving feedback when the students do the task and present the task

2) Feedback for Student to Student (feedback from student to student) that involves students in learning process where students assess the result of their friend's work, this self-assessment gives students control on their activities in learning

3) Feedback for Student to Computer involves directing students to use technology to do tasks and problem-solving activities outside of their classes and to receive centralized feedback from their teachers or their assignments

4) Feedback for Student to Self when the students get feedback and comments from teachers and friends on the tasks they do, will lead to a situation where he is aware of the location of the error and trying to fix it.

b. The types of feedback according to Schunk (2008)

1) Performance Feedback that focuses on the accuracy of work and includes information that is valuable.

2) Motivational Feedback that provides a comparison of skills between students with one student the other

3) Attribution Feedback links the performance of one student to another in an attempt to increase motivation.

4) Strategy Feedback is a feedback that reveals to students how best to apply a way or strategy and how it can be used to improve their skills.

Richards and Lockhart share feedback into two types, the first being Feedback on Content and Feedback on Form. Feedback on content 
includes vocabulary errors, grammar and pronunciation or pronunciation. Whereas feedback on form should at least consider some things like; (1) whether the mistake made by the learner must be corrected, (2) what type of error should be corrected to the learner and (3) how the fault should be corrected.

\section{A. When and How Feedback is Applied}

Learners and teachers have different preferences about error correction and provide feedback. Nunan reported that 'adult learners in Australia see error correction as very important, while their teachers do not value it as important.' Similar findings have been found elsewhere (Richards and Lockhart). It is also very important to know for teachers when and how to fix errors. Allwright and Bailey noted that teachers often correct a student's utterance simply because they do not expect what he hears, that's what's called "class discourse errors." They also show that teachers are trying to help students move forward between their language developments. "Mistimed" means an improvement to the errors of learners that the teacher fails to understand understands even more so on an inappropriate level of child development. In fact, Gower, Phillips and Walters reported that the correction depends on the purpose of the activity. If the focus is on accuracy, the controls and corrections made by the teacher will be tight and if the focus is on more fluid then direct control and correction by the teacher will be rarely done (Gower, Phillips and Walters, 1995).

Richards and Lockhart formulate feedback strategies both on Content and on Form.

Some strategies of giving feedback content:

1. Acknowledge the correct answer: the teacher confesses by saying 'Good', Yes' or 'all right'.

2. Show the wrong answer: the teacher shows the wrong answer by saying "No, that's not true" or 'Mmm'.

3. Praise: provide a complement to the correct answer by saying 'Yes, very good answer'. 
4. Expanding or modifying student answers: teachers can provide more information or repeat answers for incomplete or unclear answers.

5. Repeat: the teacher can repeat the same answer.

6. Summarize: the teacher can summarize what the student or group of students answer.

7. Criticize: teachers can criticize students' responses.

Some feedback on form strategies:

1. Ask the student to repeat what he or she says.

2. Indicate errors and ask students to self-correct.

3. Comment on the error and explain why it is wrong, without having the student repeat the correct form.

4. Ask other students to correct mistakes.

5. Using gestures to indicate errors have been made.

\section{Research Sites}

This research was conducted at Universitas Islam Makassar (UIM) J1. Perintis Kemerdekaan km. 9 No. 29 Makassar.

\section{Research Variables}

There were two variables in this research that is independent and dependent variable

a. The independent variable in this research is student to self-feedback method.

b. The dependent variable in this research is students' Speaking Ability.

\section{Research Design}

This research used quantitative research methods in measuring students' speaking skills and their interested in using Student to self-feedback method. The type of quantitative research used was Quasi Experiment. Researchers divided the second semester students of English education of FKIP UIM into two groups. One group is as experimental class and other classes as control class. To deepen the results of this research, it will be continued with the provision of questionnaire as a supporter of quantitative data. 


\section{Population and Sample}

The population in this research is all English students at Islamic University of Makassar. While the sample used is the second semester students of FKIP UIM which consisted of 44 students. The researcher divided the class into 2 groups. One group is as the experimental class and the other as the control class. Therefore, each group consisted of 22 students.

\section{Research Instruments}

a. Speaking Tests

The instrument used in this research was speaking test. This instrument takes the form of an individual speaking test in the form of a monologue that was applied to the pre and post test to see the significance of the speaking developments of the research subjects.

b. Questionnaire

Questionnaire in this research was used to determine students' interest in using the student to self-feedback method and also to dig deeper the impact of the self-directed self-improvement based learning, both in terms of improvement or stagnation.

\section{Techniques of Collecting Data}

a. Speaking Tests

This test was performed on pre-test and post-test which in both tests have the same procedure only different at the time of its application, as for the procedure as follows:

1) The researcher provided some topics to be randomly selected by the students;

2) They then talked within 3 minutes about the topic chosen;

3) Assessment at the same time conducted by researchers and research members;

4) Recording process continued so that data obtained can be re-checked.

b. Questionnaire

Questionnaire was used to find out the students' interest in speaking English using the method of student to self-feedback. The questionnaire consists of 20 items (10 positive items and 10 negative items). Questionnaire was given to 
students after giving treatment related to the use of the student to self-feedback method. The statement in the questionnaire was also used to dig deeper in order to obtain more specific and detailed data about something that is considered important to be known by researchers.

\section{Techniques of Data Analysis}

Techniques of Data Analysis in this research were adopted from Heaton analysis techniques that measure fluency, accuracy and comprehensibility.

Table 1Classification Score

\begin{tabular}{|c|c|c|c|}
\hline Component & Classification & Score & Criteria \\
\hline \multirow[t]{6}{*}{ Accuracy } & Excellent & 6 & $\begin{array}{l}\text { Pronunciation is great, doesn't really get } \\
\text { much influence of mother tongue. There } \\
\text { are only a few serious phonological errors, } \\
\text { but it's clear. }\end{array}$ \\
\hline & Very good & 5 & $\begin{array}{l}\text { Pronunciation is good, but it's a little bit } \\
\text { influenced by mother tongue. The speaker } \\
\text { pronounces every single word confidently. }\end{array}$ \\
\hline & Good & 4 & $\begin{array}{l}\text { Pronunciation is influence by mother } \\
\text { tongue, the speaker pronounces the words } \\
\text { without any worry, and even there are a } \\
\text { few phonological errors. }\end{array}$ \\
\hline & Average & 3 & $\begin{array}{l}\text { Pronunciation is influenced by mother } \\
\text { tongue but only a few serious phonological } \\
\text { errors, some of which cause confusion. The } \\
\text { words are reasonably correct but awkward. }\end{array}$ \\
\hline & Poor & 2 & $\begin{array}{l}\text { Pronunciation seriously influenced by the } \\
\text { mother tongue with errors causing a } \\
\text { breakdown in communication. Many basic } \\
\text { grammatical and lexical errors. The } \\
\text { vocabulary is inadequate. }\end{array}$ \\
\hline & Very poor & 1 & $\begin{array}{l}\text { Serious pronunciation errors as well as } \\
\text { many "basic" grammatical and lexical } \\
\text { errors. No evidence of having mastered any } \\
\text { of the language skills and areas practice in } \\
\text { the course the vocabulary is incoherent. }\end{array}$ \\
\hline Component & Classification & Score & Criteria \\
\hline Fluency & Excellent & 6 & $\begin{array}{l}\text { Speak without too great an effort with } \\
\text { fairly wide range of expression. Searches } \\
\text { for words occasionally but only one or two } \\
\text { unnatural pauses. }\end{array}$ \\
\hline
\end{tabular}




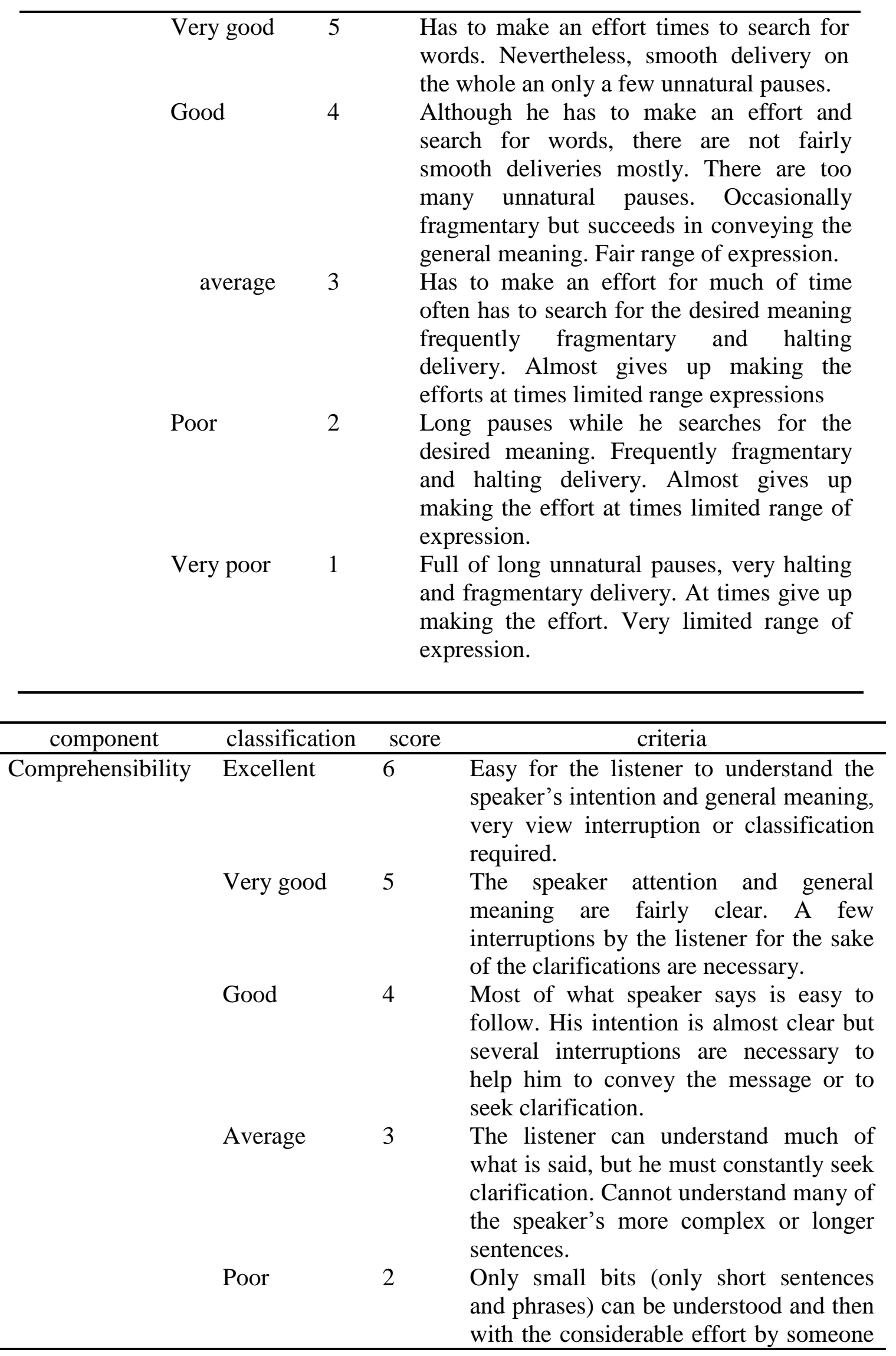


who is listening to the speaker

Very poor 1 Even when the listener makes a great effort or interrupts, the speaker is unable to clarify anything he seems to have said.

To calculate the test results of the students will be used the formula as follows:

a. Conversion and classification of student scores

The students' speaking ability score is converted using the following formula:

$$
\text { A Student Score }=\frac{\text { the Gain Score }}{\text { the Maximum Score }} \times 10
$$

Then for the classification of the above test results also use analysis by Heaton with the following classification:

Table 2Classification of the Students' Score

\begin{tabular}{|l|l|l|}
\hline Score & & Classification \\
\hline $8.1-10$ & A & Very good \\
\hline $6.6-8.0$ & B & Good \\
\hline $5.6-6.5$ & C & Average \\
\hline $4.1-5.5$ & D & Poor \\
\hline$\leq-4.0$ & E & Very Poor \\
\hline
\end{tabular}

To measure the final result or t-test value was by looking at the difference between pre-test and post-test. SPSS was used as digital statistical tool with a 0.05 level of significance.

\section{Findings}

1. The Interpretation of the Result of Students' Achievement Test

This section deals with the presentation and the elaboration of data about pretest and posttest, and the students' improvement in learning speaking before and after employing treatments. In addition, mean score of pretest, posttest, and questionnaire and standard deviation of pretest and posttest as consideration in this research is also explored further. The detailed results are provided in the further presentation of the data. 
The presentation of the data in this part is obtained through the speaking test interpretations. The interpretations are taken from mean score, standard deviation, frequency, and any other supporting source of statistical elements.

a. Scoring Classification of Students' Pre-test for experimental and control group

In this section, the researcher presents frequency and percentage of the students' score on speaking. The students' score on speaking test were analyzed in getting the frequency and percentage of the students' achievement in speaking as can be seen in the following:

Table 3 The Frequency and Percentage of the Students' Achievement on Pre-test

\begin{tabular}{lccccc}
\hline \multirow{2}{*}{ Classification } & \multirow{2}{*}{ Score } & \multicolumn{2}{c}{ Experimental Group } & \multicolumn{2}{c}{ Control Group } \\
\cline { 3 - 6 } & & $\mathrm{F}$ & $\%$ & $\mathrm{~F}$ & $\%$ \\
\hline Excellent & $9.6-10$ & 0 & 0 & 0 & 0 \\
Very Good & $8.6-9.5$ & 0 & 0 & 0 & 0 \\
Good & $7.6-8.5$ & 0 & 0 & 0 & 0 \\
Fairly Good & $6.6-7.5$ & 7 & 31.81 & 6 & 27.27 \\
Fair & $5.6-6.5$ & 6 & 27.27 & 9 & 40.90 \\
Poor & $3.6-5.5$ & 8 & 36.36 & 4 & 18.18 \\
Very Poor & $0-3.5$ & 1 & 4.54 & 3 & 13.63 \\
\hline Total & & 22 & 100 & 22 & 100 \\
\hline
\end{tabular}

Table 3 above shows that the classifications of students' score in pre-test to result for experimental group 7 (31.81\%) students' got fairly good, 6 (27.27\%) students got fair, $8(36.36 \%)$ students got poor, and 1 (4.54\%) students got very poor.

On control group, the findings indicated that the students' speaking class, there were $6(27.27 \%)$ students got fairly good, 9 (40.90\%) students got fair, 4 (18.18\%) students got poor, and $3(13.63 \%)$ students got very poor. It means that the classes were almost the same. Both of them were classified in poor.

b. Scoring Classification of Students' post-test for experimental and control group

After giving pre-test to the experimental group and control group, the researcher gave them treatment. The experimental group was taught using student 
to self-feedback and control group was taught by conventional method. The treatment was held for four meetings. At the last meeting, the researcher gave them post-test to know whether there would be the students' score improvement to both group from pre-test to post-test. The classification of students' score in post-test is shown in the following table.

Table 4 The Frequency and Percentage of the Students' Achievement on Post-test for Experimental and Control Group

\begin{tabular}{lccccc}
\hline \multirow{2}{*}{ Classification } & \multirow{2}{*}{ Score } & \multicolumn{2}{c}{ Experimental Group } & \multicolumn{2}{c}{ Control Group } \\
\cline { 3 - 6 } & & $\mathrm{F}$ & $\%$ & $\mathrm{~F}$ & $\%$ \\
\hline Excellent & $9.6-10$ & 0 & 0 & 0 & 0 \\
Very Good & $8.6-9.5$ & 6 & 27.27 & 1 & 4.54 \\
Good & $7.6-8.5$ & 7 & 31.81 & 3 & 59.09 \\
Fairly Good & $6.6-7.5$ & 8 & 36.36 & 6 & 27.27 \\
Fair & $5.6-6.5$ & 1 & 4.54 & 8 & 36.36 \\
Poor & $3.6-5.5$ & 0 & 0 & 4 & 18.18 \\
Very Poor & $0-3.5$ & 0 & 0 & 0 & 0 \\
\hline Total & & 22 & 100 & 22 & 100 \\
\hline
\end{tabular}

Table 4 above shows that the classifications of students' score in post-test to both groups are different. In experimental group improved, 6 (27.27\%) students got very good, 7 (31.81\%) students got good, 8 (36.36\%) students got fairly good, 1 $(4.54 \%)$ got fair and none of them were classified as poor and very poor.

On the other hand, in control class, only 1 (4.54\%) students were able to get very good, $3(59.09 \%)$ students were able to get good, $6(27.27 \%)$ students were able to get fairly good, 8 (36.36\%) students got fair, 4 (18.18\%) students got poor, and none of them was classified as very poor.

c. The mean score and standard deviation of students' pretest for experimental and control group.

After calculating the results of the students' pre-test showed that the control group was higher than the experimental group. It is showed in the table below: 
Table 5 The Mean Score and Standard Deviation of Students' Pre-Test

\begin{tabular}{ccc}
\hline Group & Mean score & Deviation standard \\
\hline Experiment & 5.45 & 1.34 \\
Control & 5.56 & 1.28 \\
\hline
\end{tabular}

Table 5 showed that the mean score of students' pre-test of experimental group, 5.56 is categorized as poor classification and control group, 5.45 is categorized as poor classification. Based on the table above, the researcher concluded that the students' mean score of experimental group is the same with control group. In other words, means score of the students between experimental and control group was relatively the same, it is indicated that they have the same productivity before they are given treatments.

To know the students' mean score of post-test is difference, we should decide whether or not it is statistically significant. In order to answer such question, the researcher applies. Independent sample t-test analyses by using SPSS 17.0

Table 6 The Independent Sample t-test of the Students' Pre-Test

\begin{tabular}{ccc}
\hline Variable & Probability Value & Asymptotic significance \\
\hline Pre-test & .05 & .775 \\
\hline The table above indicated that the statistical hypothesis is based on
\end{tabular}
statistics test in asymptote. Sig (2-tailed), in relation to the finding of pre-test, .775 was greater than .05 . This means that $\mathrm{H}_{0}$ is acceptable or $\mathrm{H}_{1}$ is rejected in significant level of $\alpha .05$. Those experimental and control group have the same or relatively the same ability in speaking before treatment. In other words, there was not significant different between pre-test of both group.

Since the based level of students pre-test was at the same level, the treatment was then conducted to both groups. The experimental group was taught by using student to self-feedback and control group was taught by using conventional method. 


\section{d. The Mean Score and Standard Deviation of Students' Post-Test}

In this part, the discussion deals with the argument of the difference of the students' speaking ability after treatment or post-test. Since the means score of two groups (experimental and control group) was at the same level, both groups were available to be treated. The experimental group was taught English by using student to self-feedback and control group was taught English by using conventional method with emphasizes on speaking ability. After the treatment, the students in both groups were given post-test to find out their speaking ability at the same level or not by using Independent sample t-test analyzed with SPSS 17.0. The findings of post-test are presented in table 4.5.

Table 7. The Mean Score and Standard Deviation of Students' Post-Test

\begin{tabular}{ccc}
\hline Group & Mean score & Deviation Standard \\
\hline Experiment & 7.69 & 0.90 \\
Control & 6.38 & 1.16 \\
\hline
\end{tabular}

Based on the table above showed that the mean scores of post-test of both groups is different after the treatment. The mean score of experimental group, 7.69 , which is categorized as good category and control group, 6.38, which is categorized as fairly good category $(7.69>6.38)$, the standard deviation of experiment group was 0.90 and standard deviation of control was 1.16.

To know the students' mean score of post-test is difference, the researcher should decide whether or not it is statistically significant. In order to answer such question, the researcher applies Independent sample t-test analyses by using version 17.0

Table 8 The Independent Sample T-Test of the Students' Post-Test

\begin{tabular}{ccc}
\hline Variable & Probability Value & Asymptotic significance \\
\hline Post-test & .05 & .000 \\
\hline
\end{tabular}

The table above indicated that the statistical hypothesis is based on statistics test in asymptote. Sig (2-tailed), I concluded that the probability is smaller than .05 or $.000<.05$. This means that $\mathrm{H}_{1}$ is acceptable and, of course, the statistical hypothesis of $\mathrm{H}_{0}$ is rejected, it means that the use of student to self-feedback was 
able to give significantly greater contribution than conventional method. It could be stated that the use of student to self-feedback improve the students' ability in speaking better.

This implies that the use of student to self-feedback should be taken for granted as one of the techniques that improve students' ability in speaking skill in English to the second semester students of English education of FKIP UIM

\section{The Interpretation of the Result of Data Analysis on the Questionnaire}

The purpose of the questionnaires distribution was to know the students' interest during the research. The questionnaire was distributed to the students in experimental group only after having treatments. All of the questions were answered individually based on their opinion after having treatments. Each questionnaire contained 20 statements in which 10 statements were positive and 10 statements were negative. The options of the questionnaires were (1) very high interest, (2) high interest, (3) moderate, (4) low interest, and (5) very low interest. All five options of the responses were given values differently. As mentioned in the previous chapter, the scoring of the questionnaires was analyzed statistically based on the application of Likert Scale. The result shows the students interested in learning English vocabulary by using Macromedia Flash Games Software. This is indicated by the percentage of the students' questionnaire shown in the following table:

Table 9 The Percentage of Students' Interest

\begin{tabular}{ccccc}
\hline No. & Classification & Range & Frequency & Percentage \\
\hline 1. & Very High & $85-100$ & 12 & $54.54 \%$ \\
2. & High & $69-84$ & 8 & $36.36 \%$ \\
3. & Moderate & $51-68$ & 2 & $9.09 \%$ \\
4. & Low & $36-50$ & 0 & 00.00 \\
5. & Very Low & $20-35$ & 0 & 00.00 \\
\hline \multicolumn{2}{r}{ Total } & & 22 & 100 \\
\hline
\end{tabular}

Based on the classification above, it indicated that the overall responses were only in high interest, very high interest and moderate classification. From 22 students, $12(54.54 \%)$ of them reached the high classification, very high interest. The rest $8(36.36 \%)$ students were categorized as high interest classification and 2 $(9.09 \%)$ were categorized as moderate. From all classifications, none of the 
students were categorized as low interest and very low interest. From the data, it was found that all of the students had a high interest in learning English by student to self-feedback.

Table 10 The Mean Score of Students' Interest

\begin{tabular}{ccc}
\hline Total respondent & Total of students' score & Mean \\
\hline 22 & 1821 & 82.77 \\
\hline
\end{tabular}

In relation to the mean score above, the students reached 82.77 , it can be concluded that the students of experimental group had a high interest in mastering speaking by using Student to self-feedback.

\section{Discussion}

The discussion section deals with the interpretation of test result both pretest and posttest and description of data gained from the questionnaire which is presented based on the students' interest through the method.

\section{The Students' Speaking Achievement.}

With regard to data collected through pretest and posttest, the comparison of students' speaking skill abilities in both experimental and control classes is evidenced by analyzing posttest results. It can be stated that after giving the method of student to self-feedback method, the average score of the experimental class before treatment is 5.45 and after the treatment obtained the score of 7.69. While in the control group showed the average score was 5.56 before treatment and 6.38 after treatment.

The result of posttest shows that the use of Student to self-feedback method gives significant progress toward student achievement. This means that all students can enrich their conversation; This is evidenced by the average score of students before and after treatment increased as previously stated. Achievement of speech skills is better in experimental class than control class. Statistical data based on t-test through SPSS Version 17.0 to test the hypothesis shows that the experimental class probability value is lower than alpha $(\alpha)$ where $(0,000<0.05)$. This means that $\mathrm{H} 1$ of the hypothesis is accepted.

Student to self-feedback is the right method to improve students' speaking ability. They are taught how to rate their own performance (performance). 
Lecturers train them by asking them to observe each other than assess the performance of other friends, and then provide feedback based on their observations. By observing and giving feedback to others, the student at the next stage will automatically observe his own performance and gain feedback for him / her. Through this student to self-feedback, a student can know the extent to which the material has been taught they can master. With student to self-feedback also, students can correct their own ability, or in other words as a corrective suggestion on student's own learning progress.

\section{The Students' Interest}

Questionnaires were given to students to know the statement about student's interest in applying student to self-feedback method in improving speech skill. Based on the questionnaire results related to the experimental class, student interest is predominantly classified as high interest. There are $2(9.09 \%)$ of them moderate, and none are low or very low. From these results, $8(36.36 \%)$ of students are high and $12(54.54 \%)$ of students are very high. From this fact, it is shown that the way the lecturer in explaining the material is closely related to the interest or the student's response to the lecturer.

The results of the questionnaire given after the posttest indicate that the student is interested in applying this method. Questionnaires were given to the experimental class after posttest to find out the students' interest in using the student to self-feedback method in learning to speak. Based on the questionnaire analysis, the researcher concludes that the students are interested to learn to talk through this method.

The students in the experimental class generally agree with the application of this method because it can build their confidence and they feel more enthusiastic in learning to speak. It can be seen from the average score of the questionnaire, which is 82.77 which is categorized as interesting.

\section{Conclusion}

Based on the findings and discussion in the previous chapter, the researcher concludes that: 
1. The use of Student to self-feedback method improves the speaking ability of the second semester students of English education of FKIP UIM.

2. The use of Student to self-feedback method is very interesting for the second semester students of English education of FKIP UIM.

\section{Suggestion}

Based on the conclusion above, the researcher formulate some suggestions as follows:

1. Teachers or lecturers should be more creative in managing English teaching materials to improve speaking skills such as by using the student to selffeedback method.

2. English teachers or lecturers are suggested to use the student to self-feedback method in teaching speaking because it is effective to improve student's learning achievement, interesting, and able to increase student's selfconfidence.

\section{References}

Akhter. 2007. Giving Feedback and Correcting Errors in ESL Classroom. BRAe University, Dhaka, Bangladesh

Anggraeni, dkk. Pemberian Umpan Balik (feedback) Terhadap Hasil Belajar dan Self-Efficacy Matematis Siswa Kelas VII SMP. Skripsi FKIP UNTAN. Pontianak

Arikunto, S. 2009. Dasar-Dasar Evaluasi pendidikan. Edisi Revisi. Jakarta : PT. Rineka Cipta

Brown, H. Douglas. 2000. Principles of Language Learning And Teaching. New York:Longman

Grauberg, Walter. 1997. The Elements of Foreign Language Teaching. Clevedon: Multilingual Matters, Ltd.

Hall, T. Simin. 2007. Improving Self-Efficacy in Problem Solving: Learning from Error and Feedback. Disertasi. Greensboro: The University of North California

Herman, Y. 2005. Pengaruh Umpan Balik Tes Formatif dan Gaya Kognitif terhadap Hasil Belajar Mata Kuliah Statistika (Studi Kasus pada 
Mahasiswa Jurusan PAI UNISMA Bekasi). Jakarta : Program Pasca Sarjana UNJ.

Race. Using Feedback to Help the Students to Learn. The Higher Education Academy.

Richards, Jack C, Lockhart, Charles.1997. Reflective Teaching in Second language Classrooms. United Kingdom: Cambridge University Press

Schunk, Dale H., Pintrici, Paul R., \& Meece, Judith L. 2008. Motivation in Education: Theory, Research, and Applications Third Edition. New Jersey: Pearson Prentice Hall

Seruni dan Hikmah.2014. Pemberian Umpan Balik dalam Meningkatkan Hasil Belajar dan Minat Belajar Mahasiswa. Jurnal Formatif 4(3). Jakarta : Universitas Indraprasta PGRI.

Sholihin. 2013.

Definition

of

Speaking

Skill.

http://rujukanskripsi.blogspot.co.id/2013/06/definition-of-speakingskill.html. 26 April 2016.

Suhadi. 2008. Umpan Balik dalam Pembelajaran. http://www.suhadinet.wordpress.com. 10 februari 2013.

Thronbury, Scott. 2005. How to Teach Speaking. Longman.

Ulfa.2013. Metode Speaking Bahasa Inggris.

http://hideyashu.blogspot.co.id/2013/01/makalah-metode-speaking-bahasainggris.html. 26 April 2016 